\title{
Immigration and Domestic Politics in South Africa: Contradictions of the Rainbow Nation
}

\author{
Vernon D. Johnson \\ Western Washington University*
}

The region of Southern Africa has been part of the global capitalist system since its inception in the late $15^{\text {th }}$ century, when Portugal incorporated Angola and Mozambique into its empire. In 1652 the Dutch East India Company established a "refreshment station" at the Cape of Good Hope for ships travelling between Europe and the Far East. ${ }^{1}$ From that time the region has experienced several periods of deepening incorporation into the global system.

Since the dismantling of the system of white supremacy known as apartheid in 1994, The Republic of South Africa's historic position as the hub of the regional economy has continued, and today it is also vying for economic leadership of all of sub-Saharan Africa. A system of migratory labor which operated throughout Southern

* Acknowledgements are due to Alexandra Wiley (Master's candidate) and Teadora Mladenovich (undergraduate) for their labor as research assistants on this project. 
Africa was central to the developing of both mining and agriculture in South Africa. With the demise of apartheid, as the strongest economy on the continent, South Africa has now become a magnet for immigrants from all over Africa. Yet, as a country that went through a long struggle to end white supremacy and bring democratic rule, the post-apartheid South African government had the huge responsibilities of uplifting the Black majority from poverty and constructing a political mythology that would unite citizens of all races around that project. During the recent World Cup Soccer tournament, the country received a great deal of positive publicity for its pursuit of a "Rainbow Nation" embracing the identities of its most important constituent groups (Africans, Europeans, Coloureds, and Asians). The broad humanism symbolized by Nelson Mandela, that had characterized the anti-apartheid struggle, seemed to be on a firm footing in the post-apartheid era.

Contradicting this image, however, were the xenophobic attacks on African immigrants that occurred in May, 2008. During this tragic episode 62 people were killed, hundreds were injured and over 30,000 displaced from their homes amidst widespread looting and destruction of homes and businesses. And in July 2010, as the Western press waxed euphoric over the human and administrative successes of the World Cup ${ }^{2}$, renewed attacks on African immigrants immediately following the tournament were reported in the African and online media. ${ }^{3}$ These events raise questions regarding the limits of inclusivity for this nation which owes so much to the world for its ability to bring about political transformation. This article offers an analysis of immigration policy and politics in South Africa as they interface with the daunting socioeconomic problems inherited by the African National Congress government. With its role as a regional and continental economic hub, how are we to understand the xenophobia gripping South Africa? The article will address this question from a global-system perspective. Subsidiary 
questions to be addressed are how has South Africa been structured into the evolving world system been since the $17^{\text {th }}$ century? What role has immigration played in the country's economic and political development? How do we explain post-apartheid waves of xenophobic attacks on African immigrants? What has been the response of government and progressive actors in civil society to xenophobia? What are the prospects for enlightened immigration policy as South Africa goes forward?

\section{The Global System Paradigm}

The analytical framework utilized here is indebted to the world-system paradigm developed most notably, by Oliver $\mathrm{Cox}^{4}$, Andre Gunder Frank ${ }^{5}$ and Immanuel Wallerstein. ${ }^{6}$ These scholars saw nation-states as part of an evolving world-system which was fundamentally capitalist. Their analyses were insightful, but they were criticized for being economic determinists. Led by Robert Cox a group of scholars (including this author) began to posit that there is a global system with several interconnected and overlapping spheres. ${ }^{7}$ In a vein very similar to Sklair, I argue that the global system is composed of three spheres: a global economy, which originated in the late $15^{\text {th }}$ century, a global polity, or system of states, established after the Peace of Westphalia in 1648, and a global civil society emerging during the British anti-slave trade movement of the late $18^{\text {th }}$ and early $19^{\text {th }}$ centuries. The three spheres of the global system are material and institutional structures, but they are also ideological structures, because actors in each sphere are animated by values and principles. The ideology of the global economy is capitalism. It operates to permit the "private accumulation of wealth via the trade of goods and services in the market." 8 The ideology of the global polity is realism. The global system of states is anarchical. Therefore, states are preoccupied with security: the maintenance of control over their populations and territories. It is for this reason that states traditionally have been preoccupied with maintaining 
large military establishments. But as we shall see from the present analysis, security often derives from humane policy outputs rather than force.

The ideology of global civil society is humanism, or human rights. "Global civil society is the sphere in which private interests are aggregated into social values, ideologies and political alliances transnationally. It is based upon private nongovernmental organizations (NGOs) operating across national boundaries." 9 Bowles and Gintis (1986) have argued that liberal discourse for over 200 years has involved antagonism between two sets of rights: property rights and personal rights. ${ }^{10}$ "Global civil society, as configured here, includes (value-based) interests and movements associated with capital" and property rights, and social movements arrayed against it. We often associate human rights discourse with support for the downtrodden and the marginalized, but capitalists and their allies are human too. What Bowles and Gintis see as a clash between poles within liberalism can also be viewed as a clash between "differing kinds of human rights." 11

The foregoing discussion was necessary to serve as a theoretical backdrop to understanding South Africa's progressive incorporation into the global system over the last three and a half centuries. The country's experience of initially being on the periphery, and then the semi-periphery of the global economy, then a player in the global polity of states, and finally, the focal point of clashing interests in global civil society illustrates the utility of

* This is a revision of my previous work in which I have argued that the ideology of global civil society is liberalism (Johnson, 1993, 2003). The humanism I refer to here is derived from Renaissance humanism which began to articulate a secular sphere, and also a civil society of associational life not dictated by the state. It was humanism because the individual and human values, not religious doctrine, were of central importance. Enlightenment liberalism promoting individual rights (and by the 20th century, human rights) is the progeny of Renaissance humanism (see Hankins, 2000; 3-4, 277-78 for a critical discussion of this view). 
the tri-partite global system as an analytical device. ${ }^{*}$ The South African liberation movement was able to mobilize actors from global civil society around humanist ideology to pressure Western states and capitalist multinational corporations to compel the South Africa government to end apartheid. Tri-partite global system theory is also useful in explaining historic South African immigration and the shifting responses of the country toward the issue; as the following narrative will show.

\section{South Africa's Structuration into the Global System} The Global Economy

In 1679, the Dutch East India Company began to grant land to European settlers to stabilize the colonial holding and stimulate commodity production for trade with ships passing through. Forced immigrants in the person of slaves were also critical to the workforce of the Cape, and the trade in slaves was a significant element in the region's ties to the emerging global economy. That rudimentary incorporation at the periphery of the world economy was deepened with the discovery of diamonds in the Orange Free State in 1867, and more profoundly, of gold at Witwatersrand in 1886. Although the gold was plentiful the grade of the ore was relatively low. Though thousands of British and other European immigrants arrived, the poor grade of the ore made the deposits most profitable if worked by the cheaper African labor. Thus, as Leonard Thompson reports, "by 1899 , the industry, in which 60 million pounds had been invested, was producing $27.55 \%$ of the world's output of gold, Johannesburg had 75,000 White residents, and the gold-mining companies were employing 100,000 Africans." 12 Buoyed by the * In Wallerstein's (1974) model for the world-system core countries are the most advanced economically. Peripheral areas are incorporated into the system by core states to be exploited for primary products in agriculture and mining. The semi-periphery is an intermediary stratum of states that become semi-industrialized, export manufactured goods to the periphery, and continue to produce primary goods for core. 
accumulation of capital from mining, European settlers began to industrialize South Africa over the next generation. The country moved from the periphery to the semiperiphery of the world economy, but the critical dependency on African labor to realize European goals would plague the country throughout the twentieth century.

\section{The Global Polity}

South Africa's early involvement in the global polity of states was similar to that of any colonial area. It was not an actor in its own right, but merely a pawn in interimperialist struggles. As a result of the Napoleonic Wars Great Britain took control of the Cape of Good Hope from the Netherlands in 1806. The next century was dominated by Dutch migrations away from the Cape and British interventions, at first to secure the frontier vis-a-vis the Africans, and finally to control diamond and gold production. British-Dutch conflict over the mineral industries culminated in the Second Anglo-Boer War (1899-1902), in which Britain emerged victorious and took control over the entire region paving the way for the formation of the Union of South Africa in 1909. The Union became a selfgoverning dominion of the British Empire.

The twentieth century history of race and class antagonism and capitalist industrialization in South Africa is beyond the scope of this article, but it has been amply chronicled by others. ${ }^{13}$ South Africa went from being a respected second tier player in the power politics of the two world wars to being a pariah state under relentless human rights pressure because of its white supremacist system. The Southern African region as a whole was the land of intransigent white settler colonialism. During the 1960s and 70s African guerillas won their self-determination against white rule through a combination of war and diplomacy in Mozambique, Angola and Zimbabwe. Allied with other states in the region, they formed the Frontline States, a diplomatic bloc advancing the cause of African majority rule in South Africa (and its Namibian 
colony). As each of those states gained their independence, whether by war or peaceful means, their transfer of immigrant workers to South Africa tended to drop precipitously. ${ }^{*}$ Thus, in terms of the narrative offered here, the growing pressures emanating from the global polity problematized South Africa's access to the foreign black labor upon which it had become so critically dependent. ${ }^{14}$

\section{Global Civil Society}

Following the 1960 Sharpeville Massacre in which 69 peaceful protesters were killed international human rights-oriented pressures against South Africa emanating from global civil society increased. Over the next three decades trade unions, artists, students, the sporting community, and finally multinational capital would become activated on a global scale against apartheid.

Against the foregoing backdrop, contemporary South Africa can profitably be understood as a product of the conflicting ideologies defining the activity at the three spheres within the global system. Humanist values emanating from global civil society were able to successfully compel Western states who professed to support human rights to adopt economic sanctions against South Africa. In doing so humanism trumped the logic of profit animating corporate actors in the global economy. South Africa is deeply indebted to foreign publics and states for their role in its political transformation. It owes a particular debt to the African bloc of states at the UN and the Organization of African Unity for their diplomatic support in international forums over the decades. That debt is perhaps most profound to the states of the Southern African region who braved South African destabilization as they aided and abetted exiled guerrillas of the African National Congress and the Pan Africanist Congress. Global civil society has a deep psychological investment in a postapartheid South Africa in which the races can live togeth-

* Botswana, Lesotho, and Swaziland, the last two virtual economic satellites of South Africa, bucked this trend. 
er in harmony and prosperity. Africans fleeing political instability and economic dysfunction in home countries have more immediate material needs, and it should come as no surprise that they have been flocking to this nation with the strongest economy on the continent. Thus, in the post-apartheid era South Africa continues to be challenged by its location in the three-tiered global system.

\section{Post-Revolutionary South Africa's Development Strategy}

In the time between the release of Nelson Mandela from prison in 1990 and the first democratic elections in 1994 the global system experienced historic structural changes, as the socialist bloc evaporated and market capitalism reigned supreme. With no possibility of allying with a statist socialist bloc available the ANC had no choice but to fall in line with the "Washington consensus" of neoliberalism, if it hoped to return foreign investment to the economy after the imposition of sanctions in the previous decade. Accordingly, the government enunciated its "Growth, Employment and Redistribution: A Macroeconomic Strategy" (GEAR). GEAR emphasized containing government expenditure, lowering fiscal deficits and inflation, deregulation, privatization and a generally minimalist approach to state intervention in the economy. ${ }^{15}$

South Africa's economic performance as it relates to improving the quality of life of the poor majority since the end of apartheid is mixed. Economic growth rates steadily improved from an average of $2.9 \%$ per annum (1994-2000) to $4.3 \%(2001-07)$, with rates for the last three of those years at $5 \%$ or better. ${ }^{16}$ After rising sharply under free market policies in the late 90 s, unemployment has dropped more recently; and poverty rates have decreased steadily since 1995. Moreover, per capita incomes have increased. Still, South Africa's Gini coefficient score (measuring income inequality) of 0.679 in 2010 made it "the most unequal country in the world." 17 This indicates that, although the poor have gradually been doing better, 
the rich have been doing better still. The HIV/AIDS epidemic also remains stubbornly high. Over 20 percent of the adult population is HIV positive, a big reason why life expectancy has dropped to around 50 years. After a halting start under Mandela, the Mbeki administration finally began to make headway in the provision of key services such as housing, electricity, clean water and access to sanitation after the millennium. ${ }^{18}$ Inequity in the manner of delivering education, however, remains a big issue. And the unemployment and poverty rates, at 26.8 and 43 percent respectively, remain far too high to give comfort to political elites. ${ }^{19}$ By many standards South Africa could be seen to be making satisfactory progress in the years after apartheid, but the country is suffering from a revolution of rising entitlements, in which the long-suffering masses are impatient and increasingly restive.

\section{Constructing the Post-Revolutionary South African Nation}

Successful modern nation-states require a national cultural myth to provide a sense of peoplehood that can galvanize the population for the task of socioeconomic development. Revolutionary regimes usually come to power with such a myth, and seek to use it to provide social glue as they try to transform society. In the case of South Africa, the most complex revolutionary society in Africa, the question of the myth upon which post-revolutionary society would proceed was left unsettled. From the 1940s successive discourses on African nationalism, nonracialism, multiracialism, and Black Consciousness have been advanced. In the tumultuous decade before transformation in 1994, and for all of the time since then, each of them can be heard in the public discourse. ${ }^{20}$ After the emotionally wrenching process of the Truth and Reconciliation Commission, Archbishop Desmond Tutu declared that South Africa was the "Rainbow Nation." This updated version of multiracialism was compelling and came to be used commercially and in official public relations 
(i.e., its ubiquitous presence during the World Cup Soccer Tournament).

In popular parlance, none of these three projects has much to do with immigration in particular, or South Africa's relationship with the outside world in general. Nonracialism, to the extent that it is associated with human rights and the equality of all in the constitution, taps into global norms and expectations. The African Renaissance includes an argument for South Africa's political, economic and cultural leadership in Africa. Arguably, the Rainbow Nation is the most popular of the three, but it is a South African-centric notion. Though these national myths may be in contention, commentators use each of them to excoriate the government for not living up to its historic, moral, or even constitutional obligations concerning the rights of immigrants. ${ }^{21}$ The problem is that poor Black South Africans are not primarily concerned about foreigners. They want post-revolutionary South Africa to deliver the goods to them. Yet, for an emerging economy like South Africa, the in-migration of both skilled and relatively cheap lesser-skilled labor is also crucial to its overall development prospects. The next section will discuss post-apartheid immigration policy.

\section{Emigration and Immigration in Contemporary South Africa}

European settlers brought self-conscious modern statecraft to Africa, and South Africa is the place witnessing the most numerous and dynamic industrializing settlers in Africa. As a consequence, South Africa represented $22.7 \%$ of Africa's total Gross Domestic Product in 2006.22 Add to this the fact that it is a functioning democracy, and it is no wonder then that the country has become a magnet for people seeking economic opportunity or political refuge from all over the continent.

As I have tried to demonstrate, South Africa was beset with domestic challenges at the inception of its democracy in 1994. Given its history as the centerpiece of a 
system of regional migratory labor and the progressive ideology of its rulers, one might have thought that the country would see more opportunities than challenges in its position as a magnet economy for the African continent. For nearly a decade after that the ANC government continued to operate under the Aliens Control Act of 1991, often called “Apartheid's last act," because it was designed in the interests of the old regime, not those of one with progressive aspirations like the ANC. ${ }^{23}$ Sally Peberdy trenchantly summarizes the state of affairs at the millennium.

The Act remains (in the words of its principal drafter) "a negative piece of legislation" (Tredoux, 1997). Although the procedures for immigration to South Africa have not changed radically since 1994, barriers to entry have been raised. Legislative amendments, new regulations and a computerized National Movement Control System are all designed to build higher and stronger hurdles and control. New categories of permanent and temporary residence have been introduced in an attempt to gain better control over the kinds of immigrants and migrants entering South Africa. Restrictive policies have been accompanied by an unwelcoming attitude to immigrants and migrants, particularly those from the SADC region and the rest of Africa. ${ }^{24}$

Exceptions were made via amnesties in the mid-nineties granted to contract miners, and also undocumented workers from member states of SADC and Mozambican refugees. These last two groups had to have lived in South Africa for at least five years.

The posture toward undocumented workers from elsewhere, however, was more repressive and focused almost exclusively on Black Africans. For the rest of the decade a variety of measures were taken "to raise the rates of identification, arrest, detention and repatria- 
tion of undocumented (im)migrants" and" deny access to services like health care, education and utilities to undocumented (and other) migrants." 25 It is noteworthy that before 1994 Europeans dominated legal immigration into South Africa, and they continued to do so until 1998. Since then legal immigrants from Africa, and to a lesser extent Asia, have dominated, and simultaneously, harsh measures against illegal immigrants have become more salient. From 1990 to 1999 we see an increase in the numbers of deportations from approximately 50,000 to nearly 200,000. After a drop around the millennium, deportations spiked again reaching over 250,000 by $2006 .{ }^{26}$

Sometime after the millennium, with economic growth stagnant and a growing skills gap apparent, the ANC elite began rethinking the barriers to immigration inherited from the old regime. The Aliens Control Act came under increasing criticism as elements of it were judged unconstitutional over the years. ${ }^{27}$ The brain drain was also being recognized as a significant problem for South Africa. Skilled professionals began to leave the country in the 1980s, as the levels of unrest grew. After apartheid emigration continued "for an array of reasons including job opportunities, wage differentials, working conditions, crime, and as a side-effect of affirmative action policies that are perceived to limit career prospects for the country's White minority". ${ }^{28}$

With this new awareness of its slipping position among the emerging economies, South Africa began to move in a more aggressive and enlightened manner on both domestic and regional immigration policies. A new Immigration Act was passed that accepted South Africa's role in the "age of globalization," placing greater emphasis on admitting skilled workers, while continuing to crack down on illegal entrants (Immigration Act, 2002: 2-3). ${ }^{29}$ South Africa was still trying to keep certain classes of immigrants out of the country, but it did need to retain its own skilled labor force and attract such workers from other countries. The 2004 amendment to the Act placed 
added emphasis on economic growth, and the need for "exceptionally skilled" foreign labor. ${ }^{30}$ Despite this desire for skilled labor, the preoccupation of both acts with controlling both permanent and temporary residency was also apparent. As Crush and Dodson observe:

The main categories of temporary residence are: work permits, treaty permits, corporate permits, business permits, student permits, retirement permits, exchange permits, asylum seekers permits, visitor's permits, cross-border passes, and relative permits. ${ }^{31}$

Four of the categories listed allow employment (work, treaty, corporate, and business), while "most of the other categories prohibit employment altogether."32

Although exact numbers are impossible to ascertain the government arrived at a figure of 322,499 South Africans leaving the country from 1970-2001.33 This has led to concern over an emerging skills gap. Predicting a 1.2 million person skills-shortage by 2014, the government established the Joint Initiative on Priority Skills Acquisition (JIPSA) in 2006. This "initiative identifies five areas where skills were in short supply: engineering; city, urban and regional planning; artisan and technical skills; management and planning skills in education and health; and math, science and language teachers" (Landau and Kabwe-Segatti: 25). ${ }^{34}$ JIPSA signaled that South Africa was coming to grips with its position in the global economy.

When we examine South Africa's stance on immigration within the Southern African region we see a similar trajectory of gradual movement from defensive to more enlightened policies. The mission statement of the Southern African Development Community committed member states to all of the central principles of the age of globalization.

The SADC Mission is to promote sustainable and equitable economic growth and socio-economic development through efficient productive systems, deeper co- 
operation and integration, good governance, and durable peace and security, so that the region emerges as a competitive and effective player in international relations and the world economy (emphasis added). ${ }^{35}$

Leadership in the advancing and accelerating regional economic and political cooperation within SADC should have been a "no-brainer" for South Africa. It should have been poised to play a role in the region similar to that of Brazil in the evolution of the Common Market of the South (MERCOSUR), which envisions an integrated South American economic community. But as South Africa took its seat as a full member of SADC following its liberation, it sent chilling messages to fellow community members regarding its willingness to accept freer movement of peoples across the region. In fact, until 2006 the ANC government did not explicitly link immigration from anywhere to its overall development strategy. ${ }^{36}$ South Africa, who's liberation leadership was most renowned globally for its human rights rhetoric and, who owed the global community perhaps the most for aiding in its liberation; and who also has been most dependent on migratory labor, was opposed to the free movement of peoples in the SADC region after 1994. The government saw its first responsibility as the advancement of South Africans. In that regard, it should be noted, South Africa differed little from other governments in the region, who, "with the possible exception of Botswana," were also not immigrant-friendly in their policies. ${ }^{37}$

The SADC Secretariat, attempting to create momentum around comprehensive regional integration, produced a Draft Protocol on Freedom of Movement within Southern Africa in 1995. Crush and Dodson report that

...The response to the Protocol was swift and immediate. South Africa vociferously declared its opposition and found allies in Botswana and Namibia. The Protocol was quickly rejected because of South Africa's opposition. The same fate befell a much meeker 1997 
Protocol on the Facilitation of Movement of Persons in Southern Africa. The SADC Summit of September 1998 effectively put all discussions related to the Protocol indefinitely on hold on the grounds that the provisions of the Protocol went beyond the mandate given to its drafters. ${ }^{38}$

The transformationalist regime in South Africa seemed to be abdicating its historic responsibilities toward the region.

With its economy stagnating, South Africa's initiatives within SADC and other international forums during the first years of the new millennium began to reflect new thinking. "After a decade (of) opposing ... the Protocol on the Facilitation of Movement of Persons, South Africa was among the first to sign the amended protocol in 2005."39 It also threw its weight behind the African Union's efforts linking continental immigration to development, and opened a "dialogue" with the European Union on immigration. ${ }^{40}$

Still, significant obstacles remained in executing an effective immigration strategy. The labyrinthine procedures required to parse desirable skilled immigrants from undesirable unskilled ones, and bureaucratic incapacity and ineptitude plagued the public administration even after more flexible policies were established.

Notwithstanding its institutional inefficiencies, the biggest hurdle facing South Africa as it grapples to advance in the world economy is contradictory forces emergent in its domestic polity and civil society. Key decision makers at the apex of state institutions may have become attuned to its role in the global community and what constitutes an economically rational relationship with neighboring countries, but many mid and lower level bureaucrats and the impoverished African masses have not. Even at the cabinet level Zulu leader Mangosuthu Buthelezi, in his capacity as Minister of Home Affairs, impeded the development of sounder immigration poli- 
cies for nearly a decade in league with white holdovers in the ministry. ${ }^{41}$ Accurate data collection was also a big problem. Early post-apartheid estimates of the number of immigrants in the country were based upon a series of surveys done by the South African Human Sciences Research Council (HSRC), which asked respondents how many non-South African citizens lived in their surrounding community. The methodology used for the sample was roundly criticized by regional immigration specialists at the Southern African Migration Project (SAMP) for relying too much on conjecture. As a result, in the series of four polls conducted from December 1994 to March 1996 estimates of the total number of foreigners living in the country fluctuated wildly from just over five million to over nine million. That latter figure would have been nearly a quarter of the population of just over 40 million at the time.

The HSRC eventually admitted that these polls were methodologically flawed and disavowed their accuracy. But the damage had already been done, as government officials cited the studies in public statements for years to come and media coverage of the data whipped up public paranoia of being inundated by desperate foreigners. ${ }^{42}$ In their study of coverage of immigration in the print media in the 1990s Danso and MacDonald concluded that press coverage of the issue "(did) little to inform readers about the complexities of migration, or how it fits with the broader social, political and economic development in the country or region." They found that three common stereotypes of immigrants were as "job stealers ...criminals ... and illegals." 43

SAMP conducted a more rigorous survey of attitudes toward immigrants in 1997. Among its findings were ...

...that $25 \%$ of South Africans wanted a total prohibition of migration or immigration and $22 \%$ wanted the South African government to return all foreigners presently living here to their own countries. $45 \%$ of the sample 
called for strict limits to be placed on migrants and immigrants and $17 \%$ wanted migration policy tied to the availability of jobs. In the same survey, some $61 \%$ of respondents agreed that migrants put additional strains on the country's resources. These findings suggest that levels of xenophobia or at the very least, anti-immigrant sentiments were very high. ${ }^{44}$

Nearly a decade later, public attitudes had not changed much. In another SAMP poll in 2006 "more than two-thirds" of respondents "said that foreigners used up resources such as water, electricity and health care destined for citizens. Two-thirds ... felt that foreigners from other African countries committed crimes and ... 49\% said that foreigners brought diseases such as HIV to South Africa."45 As was noted earlier, the reality was that South Africa had clamped down on legal immigration, even before 1994, as the demographic of potential immigrants shifted from white to black and the attitude toward black immigrants soured (See Table 1).

In the midst of this low-level hysteria the problem of reliable data regarding immigration remained. Official estimates, which continued to be based on the flawed HSRC studies, estimated that four to eight million immigrants were in the country at the millennium. The 2001 Census reported 1,025,072 foreign born among the population, of which 729,495 were said to be from elsewhere in Africa. SAMP estimates more recently are that there are approximately 500,000 undocumented workers among that number (Crush, et. al.: 12-13). ${ }^{46}$ 
Table 1: Legal immigration to South Africa, 1990-1999

$\begin{array}{cccc}\frac{\text { Year }}{1990} & \text { Legal immigrants } & \text { African immigrants } \\ 1991 & 14,499 & & 1,628 \\ 1992 & 12,379 & & 2,065 \\ 1993 & 9,686 & & 1,266 \\ 1994 & 6,398 & & 1,701 \\ 1995 & 5,064 & 1,628 \\ 1996 & 5,407 & 1,343 \\ 1997 & 4,102 & 1,601 \\ 1998 & 4,371 & 1,281 \\ 1999 & 3,669 & 1,169 \\ & & 980\end{array}$

Source: Jonathan Crush, Vincent Williams and Sally Peberdy, Migration in Southern Africa. Global Commission on International Migration. http://www.gcim.org. p. 9.

Adapted from South Africa, Department of Home Affairs annual reports, Statistics South Africa conducted a Community Survey in 2007. It placed the number of immigrants (legal and illegal) in the country at 1.2 million. This is less than three percent of the population of over 45 million. Yet other government officials and media sources continued to make exaggerated immigrant estimates and agitate the public imagination. The economic crisis in neighboring Zimbabwe has caused an influx of refugees from that country and made it a favorite target for wild assertions. Public officials and newspapers have stated that there were anywhere from two to three million Zimbabweans in South Africa without any empirical evidence to back up these claims. ${ }^{47}$

Perceiving that the "liberation" of 1994 was for citizens only, periodic physical attacks on foreigners began to take place shortly after the elections of that year. By 1998 enough attacks had occurred that the South African Human Rights Commission (SAHRC) and the United Nations High Commission for Refugees (UNHCR) collabo- 
rated on a Consultative Conference on the issue. Out of that meeting the Braamfontein Statement was issued declaring that

...(The) manifestation (of xenophobia) is a violation of human rights. South Africa needs to send out a strong message that an irrational prejudice and hostility towards non-nationals is not acceptable under any circumstances. Criminal behavior towards foreigners cannot be tolerated in a democratic society. ${ }^{48}$

The "Roll-Back Xenophobia Campaign" was a longerterm initiative growing out of the conference. It developed a Plan of Action "designed to ensure that the basic rights of non-South Africans are valued, protected and promoted as outlined in the South African Constitution, the Bill of Rights and the country's international obligations." 49 The Plan focused on educating government employees (including the police) and civil society "on the rights of asylum seekers, refugees and migrants in South Africa with a view to reducing negative perceptions of, and hostility towards foreigners. "50 We can see that progressive elements from global and domestic civil society were becoming sensitive to the plight of immigrants in South Africa and were beginning to mobilize to protect their human rights.

\section{How to Understand the Xenophobic Violence}

Up to this juncture we have illustrated how desperate economic conditions in South Africa under a Black government with transformationalist ambitions has created a particularly robust revolution of rising entitlements in an era of neoliberal globalization, in which governments are not expected to intervene in the economy in the name of social welfare. We have also shown how the various discourses on South African identity and development advanced since 1994, have been focused on delivering well-being to South African citizens. Yet af- 
ter a period of recalcitrance, the top leadership of the country has slogged its way toward a set of immigration policies that at least on paper, are inclusive. Many of the top leaders of the African National Congress spent years in exile and are cosmopolitan intellectuals socialized in a global civil society and polity rife with human rights discourse; but the masses of South Africans were effectively isolated from global affairs by the rigidity of the apartheid system. The leaders they had contact with during the years of struggle emphasized what a Black government would do for them and talked less about South Africa's debt to global allies or the fact of its structuration into regional and global economies. The isolation of South Africans from the world extended to the rest of Africa. South Africa was a pariah state that treated Black people as sub-humans. As we have seen, there were always significant levels of foreign migratory laborers in the mines, farms and in domestic service before and during the apartheid years. Still, their numbers peaked at around 600,000 in the early 1950s, a figure which is about half of the best estimates for immigrant Africans in the country by Statistics South Africa in 2007. Moreover, foreign Africans before 1994 were primarily seasonal workers from neighboring countries. Since then, people from all over Black Africa have been arriving, and staying, and causing heightened social tensions.

Those social tensions came to a head in May of 2008 when attacks on foreign Africans exploded across the country. Citizenship Rights in Africa Initiative (CRAI), an African continental NGO, sent a mission to South Africa "to investigate and document" the events during August of that year. The CRAI Report, published in July, 2009 summarized the episode thusly.

The violence started in poor neighborhoods of Alexandra in Johannesburg and quickly spread to other cities, including Cape Town and Pretoria. By May 31 2008, the death toll had risen to 62 , the vast majority of 
whom were in Gauteng province, where the country's economic capitol, Johannesburg, and administrative capitol, Pretoria, are located. Thousands or migrants and South Africans were victims of criminal violence; women and children were attacked and raped, and thousands had their houses and belongings looted and destroyed. The most severely affected groups were Africans from neighboring states, such as Zimbabwe and Mozambique, but migrants from more distant African countries, such as Nigeria and Somalia, as well as a significant number of South Africans, also became victims of violence. ${ }^{51}$

Estimates of those displaced from their homes ranged from 33-50,000 people. The displaced made their way to "temporary shelters, churches and police stations." 52 In the weeks following the conflagration an estimated 40,000 foreigners left the country. In response to the attacks the governments of Mozambique and Zimbabwe sent busses and trucks to the border to receive their nationals and set up emergency encampments nearby. Mozambique reported repatriating some 20,000 people. ${ }^{53}$

President Thabo Mbeki finally deployed the South African Army to quell the violence, but that was after it had gone on for eleven days. And he took three more days before making a nationally televised speech condemning the atrocities. One leading newspaper called on him to resign. Politicians from all the major parties engaged in finger pointing, and Mathews Phosa, Treasurer-General of the ANC, also suggested that Mbeki step down. ${ }^{54}$

The introduction of regular army troops was effective in controlling the violence, which was over by the end of May; but the government response to the broader humanitarian crisis was inept. There were jurisdictional battles between the city of Cape Town and the Western Cape province over who should administer refugee camps. Around the country numerous camps housing thousands of people were opened, but by August when 
the CRAl mission was touring, many of them had been closed, leaving the displaced to uncertain futures. The camps that remained open were overcrowded and poorly run. ${ }^{55}$ Civil society-based organizations, however, seemed to be more effective in their responses.

...Standard Bank and the Nelson Mandela Foundation and its affiliates were among the many institutions that donated finds. UNHCR provided 2,000 tents, 7,000 blankets and 2,000 sleeping mats. A number of organizations provided humanitarian assistance such as potable water and blankets at different camp sites. While some provided food, others provided food, others such as Medicines Sans Frontiers provided medical clinics. A number of religious institutions of different denominations housed and provided for victims. ${ }^{56}$

In Gauteng and the Western Cape Provinces the South African Human Rights Commission (SAHRC) held meetings with a range of community-based (CBOs) and faith-based (FBOs) to share experiences growing out of their efforts in response to the upheaval. The Gauteng meeting "mandated the Center for the Study of Violence and Reconciliation to coordinate CSO efforts on behalf of the displaced." In the Western Cape "a Task Force was formed between the Western Cape provincial government and the national government and CSOs to prevent violence against foreign nationals, and to provide humanitarian and other forms of assistance where necessary." 57 Under the crisis conditions actors from domestic civil society and the state demonstrated their commitment to human rights principles.

In June and July of 2010 South Africa hosted the World Cup Soccer tournament. There was much speculation, positive and negative, regarding the prospects of holding such a large-scale event on African soil for the first time. Would there be sufficient accommodations for visitors? Would the high speed trains and airports be ready 
in time? Could the authorities control crime with tourists from all over the world in attendance? Would potential visitors stay away? Though most of the tourists would be from the White world, and the attacks of 2008 where directed at Black people, the xenophobia sent a disturbing message to the global community. Happily, the World Cup came off without any sensational moments of violence. "40,000 extra police" were employed during the tournament, and "special courts" were constituted, "meting out swift---and often harsh---sentences, in contrast to South Africa's usually glacial pace of justice."58 South Africans of all races had benefitted from the influx of tourists and the pulling together to make the event come off smoothly. The international goodwill of the 1980s and 90s was recaptured, and South Africans basked in the euphoria.

But even as the tournament was winding down there were signs that the euphoria might be unjustified. Ten people were killed in several incidents in the two weeks following the tournament. The largest scale attacks took place in the Western Cape. On the night of the World Cup final in Mbekweni Township near Paarl 250 immigrants were "escorted to safety by police officers when locals began looting their shops." Two Somali shopkeepers were killed in nearby Worcester. ${ }^{59}$ And Somali shops were also targeted in the sprawling Khayelitsha Township in Cape Town as the attacks spread locally (Prince and Jassiem, 2010). ${ }^{60}$ There was also unrest at the Kya Sands township of Johannesburg. The worst incident there involved a Malawian man being killed "and having his genitals cut off." 61 Wary of a repeat of the atrocities of 2008, many Zimbabweans fled for home, despite the fact that many may have been refugees escaping from the Mugabe dictatorship. In partnership with the UN-based "International Organization for Migration ... Medicins Sans Frontieres and World Vision," Zimbabwe set up tents at the Beitbridge and Plumtree border crossings with supplies of blankets, laundry soap and buckets for those coming across. Nationals from Zambia and Malawi were also reportedly, 
among those fleeing. ${ }^{62}$

The immediate state response was mixed. The army was quickly sent into Johannesburg to control disturbances there, and as we have noted, the police responded swiftly to the larger scale rioting in the Western Cape. Still, President Jacob Zuma led a chorus of high officials who initially denied that the attacks were xenophobic. The government referred to see them simply "as criminal acts."63 However, in Gauteng, where Johannesburg houses the most dense population of Black immigrants in the country, the provincial Premier, Nomvula Mokoyane "has set up a team to deal with the threat of xenophobic attacks."64 And at the national level Western Cape Premier Helen Zille announced that the government was planning to invite the UNHCR to assist it in addressing xenophobia. In contrast, forces in global and South African civil society were immediately activated at the first signs of trouble in 2010. Three CBOs in Cape Town that had been conducting educational workshops in Khayelitsha in the wake of attacks there, implored President Zuma to acknowledge the xenophobic character of the violence as he waffled in July. The South African Human Rights Commission criticized the government for its lack of response to its report on xenophobia which had been released in March. ${ }^{65}$ Simultaneously, the Western Cape Religious Leaders Forum, led by Anglican Archbishop of Cape Town, Dr. Thabo Nakgoba was convening a "special consultative forum" about community and government responses to the attacks. ${ }^{66}$ The South African state, still basking in its World Cup triumph, had not wanted at first, to admit that such horrific events were once more unfolding in its Rainbow Nation. But a forceful reaction from a civil society committed to human rights compelled the state to act, so as not to be seen as tepid in its own human rights ethos.

\section{Conclusion}

Since the early years after transformation, South African scholars have lamented the seeming contradiction 
between a revolutionary state and a constitution with a robust human rights regime and that state's harsh treatment of African immigrants. This analysis has attempted to demonstrate that over time the South African state has consciously worked to close the gap between its constitution, its historical debts and its practices in the area of immigration policy. It has also depicted the daunting social problems the country faces. There has not been the space to discuss the massive strikes and social protests that go on constantly in the country, as citizens grow impatient over the delivery of services. Given the mounting domestic problems with unemployment, crime, education, housing, HIV relief and health care in general, it is not surprising that South Africa took awhile to address the issue of immigration policy.

Since the collapse of communism and totalitarian states a generation ago, a debate on state-society relations has grown up, and within it the issue of state capacity has become salient. ${ }^{67}$ Among the central capacities of effective states are effective economic growth and development and addressing social welfare. For developing countries at the periphery or semi-periphery of the global system, the ability to deliver these policy outputs is circumscribed by the neoliberal dictates coming from the core countries of the global North. The global economy demands free markets and states that protect the sanctity of private property rights. If the faceless actors, speculating from their desktops everywhere, see signs of state-interventionist economic development, they will put their money someplace else. The masses of poor in South African domestic civil society, still mobilized by the ideals of the revolution, are demanding sweeping state intervention into market freedom to direct resources decisively toward their social welfare. If they continue to be ignored, the country could be headed toward its second revolution. And in the midst of all of this ideological combat, other forces emanating from global and domestic civil societies are exhorting South Africa to pro- 
tect immigrants in the name of universal human rights principles. At this point in history the South African state lacks the institutional capacity and the political will to pursue social welfare and immigrant rights in a concerted way. Among the three spheres of the global system, the global capitalist economy reigns supreme. States today operate outside of neoliberal dictates, only if they are big enough, like China, or stubbornly stuck in the past, like North Korea, or Cuba. For all of the sensationalism around human rights, in global power politics today, Northern capital and its concomitant capitalist states will almost always back capital over human rights in a given Southern country.

South Africa's rulers understand their impotence before the might of global capital. It is true that the ANC elite spent too many years "buying big cars and getting their hair done" after their historic triumph in 1994. They have made more serious efforts to deliver over the last half decade or so. The state does lack the trained personnel to follow through on its policies, but it also lacks the leverage to tax big capital and deficit spend in a way that might jumpstart true societal transformation. So South Africa's rulers are muddling through. I predict they will continue to do so, unless they are hit by a second revolutionary upheaval. If that moment comes to pass, I am afraid the issue of the human rights of immigrants will be swallowed up in the wrath of the South African people.

\section{Endnotes}

1 Robert Ross. "The Cape of Good Hope and the World Economy:

1652-1835." in The Shaping of South African Society, 1652-1840, Richard Elphick and Herman Giliomee, 243. (Middletown, Connecticut: Wesleyan University Press, 1988), 243.

2 For euphoria, see Robyn Dixon, "South Africa's World Cup Defies Odds," Seattle Times, A6, July 10, 2010.

3 For renewed violence, see Samuel Okocha, "Correspondent Laments Attacks on Foreigners after World Cup," Digital Journal, July 22, 2010.; Franz Wild, "South Africa Sends 
Troops to Johannesburg Suburb After Foreigners Attacked," Bloomberg, July 21, 2010.

4 Oliver Cox, The Foundations of Capitalism. New York:

Philosophical Library, 1959

5 Andre Gunder Frank, Capitalism and Underdevelopment in Latin

America. New York: Monthly Review Press, 1969

6 Immanuel Wallerstein, The Modern World-System I: Capitalist

Agriculture and the Origins of the European World-

Economy in the Sixteenth Century. San Diego: Academic Press, 1974.

7 Robert W. Cox, Production, Power and World Order: Social Forces in the Making of History.

New York: Columbia University Press, 1987; Stephen Gill, and David Law, The Global Political Economy: Perspectives, Problems and Policies. $2^{\text {nd }}$ Printing. Baltimore: JohnsHopkins University Press, 1991. Leslie Sklair, Sociology of the Global System. Baltimore: Johns-Hopkins University Press, 1991; Vernon D. Johnson, The Structural Origins of Revolution in Africa. Lewiston, New York: Edwin-Mellen Press, 2003.

8 Johnson:14.

9 Ibid.,14

10 Samuel Bowles and Herbert Gintis, Democracy and Capitalism:

Property, Community and the Contradictions of Modern Social Thought (New York: Basic Books), 1986.

11 Johnson:17.

12 Leonard Thompson. A History of South Africa. (New Haven, Connecticut: Yale University Press, 1990), 120.

13 See Thompson; Shula Marks and Stanley Trapido, The Politics of Race, Class and Nationalism in Twentieth Century South Africa. Essex, United Kingdom: Longman Group, Ltd., 1987; William Beinart, Twentieth Century South Africa. New York: Oxford University Press, 1994.

14 Jonathan Crush, Vincent Williams and Sally Peberdy, "Migration in Southern Africa," Global Commission on International Migration, http://www.gcim.org (retrieved August 5, 2010).

15 Adam Habib and Vishnu Padayachee, "Economic Policy and Power Relations in South Africa's Transition to Democracy," World Development, February(2000): 252-54.

16 Summarized from Anthony Butler. Contemporary South Africa New York: Palgrave-MacMillan Publishers, 2009), 56-57.

17 Donwald Pressly, "South Africa has widest gap between rich and poor," http://www.iol.co.za/business/businessnews/south-africa-has-widest-gap-between-rich-and- 
poor-1.707558 (retrieved August 12, 2010), quoted in Haroon Bhorat, Business Report, September 27, 2009.

18 Tim Hughes, "South Africa: The Contrarian Big African State," in Big African States, ed. Christopher Clapham, Jeffrey Herbst and Greg Mills, 158-59 (Johannesburg: Witwatersrand University Press, 2006),158-59.

19 ClA World Factbook, "South Africa Unemployment rate," Index Mundi.

http://www.indexmundi.com/south_africa/unemployment_ rate.html (retrieved August 12, 2010).

20 For extended discussions of the evolution of competing national identities in South Africa, see Robert Fatton, Jr. Black Consciousness in South Africa: The Dialectics of Opposition to White Supremacy. Albany: State University of New York Press, 1986); Julie Frederikse, The Unbreakable Thread: Non-Racialism in South Africa. Bloomington, Indiana: Indiana University Press, 1990; Ivor Chipkin, Do South Africans Exist? Nationalism, Democracy and the Identity of the People. Johannesburg: Witwatersrand University Press, 2007. David Everatt, The Origins of Nonracialism: White Opposition to Apartheid in the 1950s. Johannesburg: Witwatersrand University Press, 2010.

21 Sally Peberdy, "Imagining Immigration: Inclusive Identities and Exclusive Policies in Post-1994 South Africa," Africa Today, 48, (2001): 15-31; Natalie Jaynes, "The State of Nation Building in South Africa in Light of the Recent Xenophobic Attacks," Perspectives: Political Analysis and Commentary from Southern Africa 3(2008): 12-14.

22 “Africa GDPO Rankings 2006," Political Calculations, August 16, 2007. http://www.politicalcalculations. blogspot.com/2007/08/africa-gdp-rankings-for-2006.html. (retrived August 20, 2010.)

23 Loren B. Landau and Aurelia Kazadi Wa Kabwe-Segatti, "Human Development Impacts of Migration: South Africa Case Study," United Nations Development Programme, http://www.hdr.undp.org/en/reports/global/hdr2009/ papers/HDRP_2009_5.pdf (retrieved August 1, 2010).

24 Peberdy, "Imagining Immigration: Inclusive Identities and Exclusive Policies in Post-1994 South Africa,"17.

25 Ibid., 21.

26 Landau and Kabwe-Segatti, "Human Development Impacts of Migration: South Africa Case Study," 11.

27 Bradley Rink, " Lessons from a Rainbow Nation: A Look at South Africa," Rainbow SIG Signals Newsletter, (2003) http://www.indiana.edu/ overseas/lesbigay/ 
vol9_2/92souafrica.html, (retrieved August 17, 2010); Jeff Handmaker, Lee Anne De la Hunt, and Jonathan Klaaren, Advancing Refugee Protection in South Africa (Oxford, United Kingdom: Berghahn Books, 2008), 3.

28 Landau and Kabwe-Segatti, "Human Development Impacts of Migration: South Africa Case Study," 24.

29 Issuing department. Immigration Act, 2002 (City: Publisher, year) 2-3.http: / /Info.gov.za. (retrieved August 2, 2010).

30 Ibid., 3-4

31 Jonathan Crush and Belinda Dodson, "Another Lost Decade: The

Failures of South Africa's Post-Apartheid Migration Policy," Journal of Economic and Social Geography 98.4 (2007): 442.

32 Ibid., 442.

33 Statistics South Africa. Documented Migration 2003 (Pretoria:

Statistics South Africa, 2003) in Landau \& Kabwe-Segatti, 24. 34 Ibid., 25.

35 Southern African Development Community, "Mission Statement," SADC. http://www.sadc.int/index/browse/page/715 (retrieved August 15, 2010).

36 Landau and Kabwe-Segatti, "Human Development Impacts of Migration: South Africa Case Study," 29.

37 Crush, Williams and Peberdy, "Migration in Southern Africa," 24.

38 Crush and Dodson, "Another Lost Decade: The Failures of South Africa's Post-Apartheid Migration Policy," 449.

39 Landau and Kabwe-Segatti, "Human Development Impacts of Migration: South Africa Case Study," 30.

40 Ibid., 30.

41 Crush and Dodson, "Another Lost Decade: The Failures of South Africa's Post-Apartheid Migration Policy," 436-37. 42 Crush, Williams and Peberdy, "Migration in Southern Africa,"

12; Crush and Dodson, "Another Lost Decade: The Failures of South Africa's Post-Apartheid Migration Policy," 443-44.

43 Ransford Danso and David A. MacDonald, "Writing Xenophobia: Immigration and the Print Media in Post-Apartheid South Africa," Africa Today 48.3 (2001): 124-29, 132.

44 Vincent Williams, "Xenophobic Attacks in South Africa: Not a completely new Phenomenon," Heinrich Boll Stiflun: The Green Foundation, http://www.boell.de/intlpolitics/ security/africa-3460html. (retrieved August 25, 2010). 45 Ibid.

46 Crush, Williams and Peberdy, "Migration in Southern Africa," 12-13.

47 Landau and Kabwe-Segatti, "Human Development Impacts of Migration: South Africa Case Study," 6. 
48 Vincent Williams, "Xenophobia in South Africa: Overview and Analysis," Perspectives: Political Analysis and Commentary from Southern Africa, 3 (2008): 3.

49 Parsley, Jennifer. "We Are Not Treated Like People': The Roll Back Xenophobia Campaign in South Africa,"Humanitarian Exchange Magazine, October 2002.

50 Williams, "Xenophobia in South Africa: Overview and Analysis," 3.

51 Citizenship Rights in Africa Initiative, "Tolerating Intolerance: Xenophobic Violence in South Africa," Citizenship Rights in Africa Initiative, http: / / www.citizenshiprightsinafrica. org/publications/2008/CRAISAReport.July2009.pdf (retrieved August 9, 20210).

52 lbid.

53 Ibid., 12.

54 Barry Bearak, "Mbeki Calls Harm to Migrants a Disgrace," New York Times, A10, May 26, 2008.

55 Citizenship Rights in Africa Initiative, "Tolerating Intolerance," 14.

56 Ibid., 14-15.

57 Ibid., 16-17.

58 Dixon, "South Africa's World Cup Defies Odds."

59 Peter Kenworthy, "Post-World Cup Xenophobia in South Africa," Stiffkitten's Blog, http://stiffkitten.wordpress. com/2010/07/20/post-world-cuo-xenophobia-in-southafrica/. (retrieved August 10, 2010).

60 Ntasha Prince and Nurene Jassiem, "South Africa: Residents Urge Foreigners to Return," Cape Argus, July 15, 2010. (real site: http://allafrica.com/stories/201007150443. html)

61 Stiffkitten's Blog.

62 "Zimbabwe Prepares for Nationals Fleeing South Africa," Ghana News: Accra Mail,http://www.accra-mail.com/ index. (retrieved August 14, 2010).

63 Wild, "South Africa Sends Troops to Johannesburg Suburb After Foreigners Attacked," 2010.

64 Kenworthy, "Post-World Cup Xenophobia in South Africa."

65 Hlengiwe Mnguni, "Xenophobia: SA to Call in UN," News24.com, http://www.news24.com/South Africa/News, (retrieved August 12, 2010).

66 Prince and Jassiem, "South Africa: Residents Urge Foreigners to Return," 2010.

67 Atul Kohli, "State, Society and Development," in Political Science: State of the Discipline, eds. Ira Katznelson and Helen V. Milner, 84-117 (New York: W.W. Norton and Company, 2002). 


\section{Bibliography}

Bearak, Barry. "Mbeki Calls Harm to Migrants a Disgrace." New York Times, A10, May 26, 2008.

Burnell, Peter and Vicky Randall. Politics in the Developing World, $2^{\text {nd }}$ edition. New York, New York: Oxford University Press, 2008.

Chipkin, Ivor. Do South Africans Exist? Nationalism, Democracy and the Identity of the People. Johannesburg: Witwatersrand University Press, 2007.

ClA World Factbook. South Africa Unemployment rate," Index Mundi, http://www.indexmundi.com/ south_africa/unemployment_rate.html. (retrieved August 12, 2010).

Citizenship Rights in Africa Initiative. "Tolerating Intolerance: Xenophobic Violence in South Africa." Citizenship Rights in Africa Initiative. http://www. citizenshiprightsinafrica.org/publications/2008/ CRAISAReport.July2009.pdf (retrieved August 9, 2009.

Collier, Paul. The Bottom Billion: Why the Poorest Countries are Failing and What Can be Done About it. New York: Oxford University Press, 2007.

Constitution of the Republic of South Africa, 1996.

http://www. info.gov.za

Cox, Oliver. The Foundations of Capitalism. New York: Philosophical Library, 1959.

Cox, Robert W. Production, Power and World Order: Social Forces in the Making of History. New York: Columbia University Press, 1987. 
Danso, Ransford and David A MacDonald. "Writing Xenophobia: Immigration and the Print Media in PostApartheid South Africa." Africa Today 48.3 (2001): 115-37.

Dixon, Robyn. "South Africa's World Cup Defies Odds." Seattle Times, A6, July 10, 2010.

Everatt, David. The Origins of Nonracialism: White Opposition to Apartheid in The 1950s. Johannesburg: Witwatersrand University Press, 2010.

Fatton, Robert, Jr. Black Consciousness in South Africa: The Dialectics of Opposition to White Supremacy. Albany: State University of New York Press, 1986.

Frank, Andre Gunder. Capitalism and Underdevelopment in Latin: Historical Studies of Chile and Brazil. New York: Monthly Review Press, 1967.

Frederikse, Julie. The Unbreakable Thread: Non-Racialism in South Africa. Bloomington, Indiana: Indiana University Press, 1990.

Gill, Stephen and David Law. The Global Political Economy: Perspectives, Problems and Policies. Baltimore, Maryland: Johns-Hopkins University Press, 1991.

Handmaker, Jeff, Lee Anne De la Hunt, and Jonathan Klaaren. Advancing Refugee protection in South Africa. Oxford, United Kingdom: Berghahn Books, 2008.

Hankins, James. Renaissance Civic Humanism. Cambridge, United Kingdom: Cambridge University Press, 2000. 
"Human Development Index (most recent) by country," NationMaster.com. http://www.nationmaster. com/graph/eco_hum_dev_ind-economy-humandevelopment-index

Jaynes, Natalie. "The State of Nation Building in South Africa in Light of the Recent Xenophobic Attacks." Perspectives: Political Analysis and Commentary from Southern Africa. 3.08 (2008): 12-14.

Johnson, Vernon D. The Structural Origins of Revolution in Africa. Lewiston: Edwin-Mellen Press, 2003.

Kenworthy, Peter. "Post-World Cup Xenophobia in South Africa." Stiffkitten's Blog, http: //stiffkitten.wordpress.com/2010/07/20/post-world-cuo-xenophobia-in-south-africa/. (retrieved August 10, 2010).

Mnguni, Hlengiwe. "Xenophobia: SA to Call in UN." News 24.com, July 16, 2010.

Parsley, Jennifer. "We Are Not Treated Like People': The Roll Back Xenophobia Campaign in South Africa," Humanitarian Exchange Magazine, October 2002.

Peberdy, Sally. "Imagining Immigration: Inclusive Identities and Exclusive Policies in Post-1994 South Africa." Africa Today 48 (2001): $15-31$. --.. 1997. Interview by A. Tredoux, Chief Legal Officer, Department of Home Affairs.Pretoria, Guateng Province, South Africa, April 3.

Political Calculations. "Africa GDPO Rankings 2006." August 16, 2007. http://www.politicalcalculations.blogspot.com/2007/08/africa-gdp-rankingsfor-2006.html. (Retrieved August 20, 2010.) 
Pressly, Donwald. "South Africa has Widest Gap Between Rich and Poor," Quoting Haroon Bhorat. Business Report. (Sept., 28 2009).

Price, Robert M. The Apartheid State in Crisis: Political Transformation in South Africa, 1975-1990. New York: Oxford University Press, 1991.

Prince, Ntasha, and Nurene Jassiem. "South Africa: Residents Urge Foreigners To Return," Cape Argus, July 15, 2010.

Resolutions and Decisions of the Security Council: 1963. New York: United Nations, 1963, pp. 7-8. UNGA, 1961.

Rink, Bradley. "Lessons from a Rainbow Nation: A Look at South Africa." Rainbow SIG Signals Newsletter, http: / / www.indiana.edu/ overseas/lesbigay/ vol9_2/92souafrica.html. (retrieved August 17, 2010).

Sachs, Jeffrey D. The End of Poverty: Economic Possibilities of Our Tim. New York: Penguin Books, 2005.

SAPA. "Government Slack in Tackling Xenophobia: SAHRC." News24.com, July 21, 2010.

-.- “Create Jobs to Stop Xenophobia." News24.com, July 28, 2010.

-.-. "Thousands of Mozambicans Return Home." Crime and Courts. http://www.iol.co.za/news/ south-africa/thousands-of-mozambicans-returnhome-1.401432. (retrieved August 30, 2010).

Schreuder, D. M. The Scramble for Southern Africa, 18771895. Cambridge: Cambridge University Press, 1980. 
Sklair,Leslie. Sociology of the Global System. Baltimore: Johns-Hopkins University Press, 1991.

Southern African Development Community. "Mission Statement." SADC. http://www.sadc.int/index/ browse/page/715. (retrieved August 15, 2010).

--.. "Introducing SADC," Southern African Development Community, http://www.sadc.int. (retrieved August 18, 2010).

Wallerstein, Immanuel. The Modern World-System I: Capitalist Agriculture and The Origins of the European World-Economy in the Sixteenth Century. San Diego: Academic Press, 1974.

Williams, Vincent. "Xenophobic Attacks in South Africa: Not a completely new Phenomenon," Heinrich Boll Stiflun: The Green Foundation. http://www. boell.de/intlpolitics/security/africa-3460html. (retrieved August 25, 2010).

-.- (b). "Xenophobia in South Africa: Overview and Analysis." Perspectives: Political Analysis and Commentary from Southern Africa 3.08 (2008).

Wild, Franz. "South Africa Sends Troops to Johannesburg Suburb After Foreigners Attacked," Bloomberg, July 21, 2010.

“World's 50 Poorest Countries." InfoPlease. www.infoplease.com. (retrieved August 15, 2010).

"Zimbabwe Prepares for Nationals Fleeing South Africa." Ghana News: Accra Mail. http://www.accra-mail. com/index. (retrieved August 14, 2010). 